\title{
PENDIDIKAN HUKUM SEBAGAI PENDIDIKAN MANUSIA
}

\author{
Oleh \\ Satjipto Rahardjo*
}

\begin{abstract}
ABSTRAK
Hukum modern telah menimbulkan perubahan paradikmatik dari orde keadilan'. menjadi 'orde undang-undang dan prosedur' dengan adanya rasionalisasi, strukturisasi, formulasi serta birokratisasi hukum. Fokus perhatian juga bergeser dari manusia atau kemanusiaan, ke arah penekanan pada peraturan, struktur, dan prosedur. Dengan demikian hukum telah merubah menjadi suatu teknologi yang harus dikuasai secara formal oleh tenaga ahli yang khusus dididik di lembaga formal. Demikian pula kapitalisme dalam hukum dan pembelajaran hukum telah menjadikan hukum sebagai suatu komoditas yang lebih diukur secara ekonomi dan materi daripada memperjuangkan suatu keadilan. Untuk mewujudkan pendidikan hukum yang berdimensi manusia dan kemanusiaan, maka filsafat yang mendasari pendidikan hukum harus diusahakan bergeser "dari professional menjadi pro-manusia". Demikian pula para pengelola program pendidikan hukum harus mampu mendekonstruksi dan merekonstruksi hal-hal dan cara-cara yang selama ini dijalankan. Fakultas Hukum sebagai lembaga pendidikan hukum di Indonesia juga harus mengartikan hukum sebagai institusi manusia dan kemanusiaan, sehingga pendidikan hukum juga menjadi bastion dari manusia dan kemanusiaan.
\end{abstract}

Kata Kunci : Pendidikan Hukum, Hukum Modern, Pendidikan Manusia dan Kemanusiaan

\footnotetext{
* Prof Dr. Satjipto Rahardjo, SH adalah Guru Besar Emiritus Sosiologi Hukum, di Fakultas Hukum UNDIP dan staf pengajar PMIH dan PDIH UNDIP
} 


\section{A. PERUBAHAN PARADIKMATIK DALAM HUKUM MODERN}

Kalau dunia hukum boleh diumpamakan sebagai bagian dunia fisik, maka dunia hukum juga pernah mengalami fenomen big bang, yaitu saat muncul hukum modern pada abad ke-delapanbelas, seiring. dengan kehadiran negara modern. Saya sebut sebagai big bang oleh karena kelahiran hukum modern bagaikan tiba-tiba menciptakan suatu kultur kehidupan hukum yang baru di dunia. la mengantarkan kehidupan dan peradaban manusia kepada suatu momentum terjadinya bifurkulasi.

Sejak saat itu kehidupan hukum dihadankan kenada suatu nersimpangan jalan, yang satu jalan pencarian keadilan, sedang yang lain jalan yang memusatkan perhatian pada pengoperasian hukum modern. Ini menimbulkan situasi yang cukup rumit, karena keduanya hampir bertolak satu sama lain.

Sejak ribuan tahun sebelum kehadiran hukum modern, berbicara mengenai hukum adalah berbicara mengenai keadilan dan pencarian keadilan (searching for truth). Hukum itu dianggap muncul secara alami dalam interaksi antara para anggota masyarakat dengan nama yang bermacam-macam, seperti natural law, traditional, law, dan interactional law. Selama ribuan tahun kita hanya mengenal yang disebut hukum alam (natural law). Disini, dunia hukum lebih menjadi tempat pertarungan hati (baca : keadilan) daripada pikiran (ratio).

Sepanjang masa sejarah yang jauh itu, kehidupan masyarakat berputar di sekitar sumbu keadilan. Keadilan menjadi kaidah substansial.
Dinamika masyarakat dituntut oleh keinginan untuk memiliki tatanan sosial yang lebih adil. Bangsa kita mengenal adagium, "Raja adil raja disembah, raja lalim raja disanggah". Inilah konstitusi sosial pada masa itu.

Keadaan segera berubah dengan kelahiran hukum modern. Berbeda sekali dengan tatanan sosial yang lama, maka tatanan yang diciptakan oleh hukum modern sarat dengan struktur rasional yang dibuat secara sengaja (purposefun). Seiring dengan kemunculan negara modern, maka hukum modern tampil sebagai suatu institusi publik yang berciri khas (distinct). Maka tidak sembarang kaidah sosial boleh disebut hukum kecuali peraturan yang dibuat oleh suatu badan publik khusus (legislation, legislative body), diawaki oleh personel publik yang direkrut secara khusus pula, memiliki metodologi sendiri dan diadministrasi secara rasional. Sebagai bagian dari munculnya negara modern, maka kelahiran hukum modern telah merombak secara fundamental tatanan sosial yang lama menjadi suatu tatanan yang terstruktur secara rasional. Salah satu hal yang penting adalah tergusurnya keadilan sebagai satu-satunya parameter. Dengan munculnya hukum modem yang memiliki karakteristik sebagaimana disebutkan diatas, maka memasuki dunia hukum tidak lagi semata-mata berburu keadilan, melainkan mengoperasikan substansi hukum modern, baik peraturan maupun prosedurnya. Dalam ke-

\footnotetext{
Roberto Mangabeira Unger,. Law in Modern Society, N.Y. : The Free Press, 1976.hal 52-53
} 
nyataan di masyarakat, penerapan peraturan dan prosedur itulah yang lebih dominant. Pengadilan, misalnya, tidak lagi menjadi "rumah keadilan", melainkan "rumah undangundang dan prosedur" Hakim, misalnya adalah seorang yang menggenggam sertifikat, ijasah. Hakim harus direkrut dari mereka yang telah menamatkan pendidikan di fakultas hukum, bukan dicari orang-orang yang berintegritas tinggi dan memiliki rasa keadilan tinggi. Itulah, antara lain alasan saya mengatakan, bahwa telah terjadi big bang tersebut diatas. Sebuah dunia hukum baru terhampar di hadapan kita.

Pelahan-lahan sejak saat itu hukum semakin bergeser menjadi teknologi. la menjadi demikian, karena pekerjaan hukum yang sudah sarat dengan penerapan undang-undang berikut prosedur, membutuhkan keterampilan (skill) yang bersifat teknis dan teknologis. Maka kita bisa berbicara tentang teknologi berperkara. Pembacaan sepintas tentang sebuah buku dari Bailey tahun 1995 berjudul "To Be $A$ Trial Lawyer" bisa memberikan kesan tersebut. Daftar isi dari buku tersebut mencantunkan topik-topik (antara lain) berikut :

1. A Command of the Language

2. What Preparation Really Means

3. Managing $A$ Trial

4. Dealing with Judges

\footnotetext{
Bandingkan dengan, William $\mathrm{T}$ Pizzi., Trials Without Truth, NY. : New York University Press, 1999. dan Gerry, Spence, The Death of Justice, N.Y. : St. Martin's Press, 1997.
}

5. Working with a Jury

6. Calling a Witness

7. An Approach to CrossExamination

8. Arguing to a Judge of Jury

9. What Appeals Are All About

10. Computers and Their Use in the Law

Dari daftar tersebut tercermin pekerjaan macam apa yang akan dihadapi oleh para lawyers di Amerika Serikat dan keterampilan apa saja yang perlu dikuasainya. Semua sudah menjurus kepada keterampilan teknologis, seperti seorang ahli mesin yang harus menguasai mesin, bagian-bagiannya dan bagaimana mesin itu bekerja, sehingga mampu mengoperasikannya dengan baik.

Tidak ada satupun hal yang berhubungan dengan keadilan, empati, kejujuran dan modalitas spiritual lainnya. Menjadi sangat bisa dimengerti mengapa muncul keluhankeluhan terhadap bekerjanya pengadilan dan legal firms. Mempersiapkan lawyers seperti dicantumkan dalam daftar isi buku Bailey tersebut diatas menghasilkan ahli-ahli untuk memenangkan perang di pengadilan, seperti dikatakan oleh Pizzi bahwa ", "..., it shows a trial system in which winning and losing are badly overemphasized and in which quality of one's lawyers ...

\footnotetext{
${ }^{3}$ William T Pizzi. Ibid
} 
can be more important to the outcome of the case than the quality of the evidence." Pizzi bicara mengenai 'procedure addict di kalangan pengadilan, saat mengatakan "... it is also incredibly expensive as lawyers and judges in important criminal cases eat up hours and sometimes even days what should be trial time in debate over technical evidentiary and procedural issues."

Mengenai kemerosotan kualitas mengadili (tria) yang sudah lebih menjadi bisnis tersebut, pada waktu mengkritik law firms yang besar di Amerika Serikat, dengan sarkastis Marc Galanter mengatakan ${ }^{4}$

"... these are the modern firms with central directions and rationalized management presided over by full-time professional office managers. Legal services are seen as a product to be sold; clients are charged by the fraction of the hour for the time of each lawyer who works on their matter. The remnants of patrician airs and professional noblesse are further dispelled. Lawyers are more businesslike." Lebih lanjutt..., lagi, dengan mengutip sebuah pendapat, dari Galanter mengatakan,

\footnotetext{
Marc Galanter," "Mega-Law and MegaLawyering in "the Contemporary United States", dalam The Sociology of the Legal Professions, (Roberts Dingwall \& PhiliLewis, eds.), London : The Macmillan Press, 1983, pp. $152-176$
}

"... the legal profession is more concerned with the facilitation of business, with "getting things done" than with alleviating human suffering or with helping people..." Selanjutnya, "... fortified by the ideology that ... adversary confrontation will assure just results, eschews moral screening of clients interest... $A$ good lawyer is like a good prostitute ... if the price is rights, you warm up your client."

Kita telah banyak membicarakan tentang hal lawyers dan pengadilan di Amerika Serikat, tetapi rasanya kita juga sedang membicarakan kondisi hukum di tanah air sendiri. Sampai sekarang model bantuan hukum kita tidak banyak berbeda dari Amerika Serikat, yaitu kapitalistis dan liberal. Kendati sistem pengadilan kita berbeda, tetapi fenomen yang disebut oleh Pizzi sebagai "procedure addict mewarnai pengadilan dan peradilan kita dengan kuat.

Disini terjadi perubahan paradigmatik. Seperti dikatakan diatas, selama ribuan tahun kita atau masyarakat hanya berurusan dan berkepentingan dengan pencarian keadilan. Tipe orde disitu adalah 'orde keadilan'. Tetapi sejak memasuki hukum modern kita memasuki suätu tipe orde yang berbeda, yaitu 'orde undang-undang dan prosedur'. Taruhan yang dihadapi juga menjadi berbeda. Dalam orde hukum pramodern yang menjadi taruhan 
adalah 'manusia' atau 'kemanusiaan', sedang dalam hukum modern, taruhan berubah dan lebih menekankan pada 'peraturan', 'struktur', 'prosedur' dan sebagainya. Berdasarkan perubahan inilah pada intinya tulisan tentang pendidikan yang ada di hadapan pembaca dibuat.

\section{B.HUKUM BERSIFAT TEKNOLOGIS DAN MATERIALISTIS}

Supaya lebih tuntas, marilah kita bicarakan sejarah sosial yang akhirnya melahirkan, Negara dan hukum modern. Kita akan membicarakan Abad-abad Kegelapan dan Abad-abad Pertengahan, melainkan menggunakan abad ke-tujuhbelas dan delapanbelas sebagai titik pangkal. Abad-abad tersebut melahirkan Masa 'Aufklaerung' atau 'Englightenment atau 'Pencerahan' di Eropa. Para pemikir dan penulis Abad Pencerahan menggunakan kritik akal pikiran untuk memerdekakan alam pikiran rakyat dari takhayul (prejudice), dari penerimaan terhadap kekuasaan secara begitu saja (unexamined authorityi), serta penindasan yang dilalukan oleh gereja dan kekuasaan. Bendungan lama, mitos-mitos lama telah jebol oleh hambatan gelombang cara berfikir, bersikap dabn bertindak secara rasional itu. Tidak ada yang luput dari pengamatan dan ujian akal pikiran.
Rasionalitas dalam menata dan menguasai masyarakat telah menjadi kehidupan sosial menjadi kehidupan yang terstruktur dan distrukturkan ${ }^{5}$. Rasionalisasi hukum menjadikan hukum modern suatu tipe hukum yang khas (distinct), yang berbeda sekali dengan tipe pra-modern. Hukum yang mengalami restrukturisasi rasional itu berubah sifat dari hukum yang "luwes" menjadi "keras". Inggris mencoba mempertahankan suatu sistem hukum yang didasarkan pada tradisi (common law) dan karena itu merupakan perkembangan yang menarik di tengah-tengah gelombang civil law sebagai suatu legislasted system yang melanda Eropa Daratan. Dikatakan oleh Simpson, "In the common law system no very clear distinction exists between saying that a particular solution to a problem is in accordance with the law, and saying that is the rational, or fair, or just solution... Legal justification reasoning does not depend upon a finite-closed scheme of permissible justification, nor does it employed conceptions which are insulated wholly from lay conceptions. The language of the law is not a private language. The legal and extra-legal worlds are intimately associated, not separed..."

\footnotetext{
J.W. de Beus \& J.A.A. van Doorn, De geconstrueerde samanleving, Amsterdam : Boom Meppel, 1986.
} 
Karena perbedaan yang signifikan antara hukum modern dan pra-modern tersebut, maka hukum modern harus mulai dari bawah dengan mendefinisikan kembali substansi hukum serta struktur dan manajemennya. Struktur rasional yang baru tersebut terdiri dari legislasi, yudikatif dan eksekutif. Hukum berubah menjadi dunia yang asing (esoteric), memiliki "tata bahasa" sendiri (private language) yang sulit dipahami oleh 'the extralegal world.

Rasionalisasi, strukturisasi, formulasi serta birokratisasi hukum, memberikan pukulan yang mematikan terhadap eksistensi dari hukum pra-modern yang jauh lebih alami itu. Dengan perubahan besar seperti itu maka hukum modern menjadi medan berkelebatnya para aktor hukum dan proses hukum yang menjadi sarat dengan tuntutan identifikasi rasional serta persyaratan formal. Sejak saat itu bukan manusia lagi yang berkelebat, tetapi manusia-hukum, status hukum dan sebagainya. Bukan proses kemanusiaan, bukan interaksi antara manusia lagi yang terjadi, melainkan interaksi antara manusia-hukum, status hukum. Orang tidak bisa begitu saja masuk ke dalam (proses) hukum sebelum dipastikan apakah ia memiliki sekalian bukti dan kelengkapan (credentials) yang diperlukan. Tidak sekalian orang akan mendapatkan haknya, bagaimanapun ia berada di pihak yang benar, sebelum bisa mengajukan bukti-bukti yang bisa diterima oleh orde hukum modern. Tidak seorangpun atau tidak siapapun dapat menjadi hakim dan jaksa, bagaimanapun tinggi integritas dan rasa keadilannya, kecuali bisa membuktikan keputusan formal yang dikeluarkan oleh Negara.

Hukum modern yang sudah berubah tipe seperti itu membutuhkan pasukan yang akan mengawaki pekerjaan-pekerjaan yang tersedia untuk mengoperasikannya. $\mathrm{Di}$ atas sudah disebut contoh diperlukannya hakim dan jaksa yang memiliki bukti-diri formal untuk mengisi jabatan-jabatan tersebut. Itu berarti, bahwa ada lembaga yang juga dibentuk secara rasional untuk menyiapkan tenaga-tenaga tersebut. Maka dibentuklah institusi pembelajaran hukum, seperti fakultas hukum. Orang tidak bisa otodidak belajar hukum untuk kemudian melamar pekerjaan hukum.

Dalam situasi seperti ini, maka pembelajaran hukum yang menjadi pabrik yang memproduksi ahli-ahli hukum, tak dapat secara bebas menentukan apa yang ingin diajarkannya kepada para murid. la harus menyiapkan tenaga-tenaga yang nanti menjadi operator yang menjalankan mesin hukum modern. Lembaga pendidikan hukum harus mengacu kepada peta besar hukum modern dengan ciri-ciri seperti 
disebutkan di muka. Apabila hukum modern sudah lebih bergeser menjadi teknologi, maka kurikulum lembaga pendidikannyapun menjadi demikian. Dengan cara seperti ini, yaitu berubah menjadi teknologi, maka hukum sudah kurang bisa dipercaya untuk menjaga kemanusiaan, atau menjadi bastion kemanusiaan.

Ada satu aspek besar lain yang penting, yaitu masuknya kapitalisme dalam hukum dan pembelajaran hukum. Karena kapitalisme tersebut, maka hukum sudah menjadi komoditas, seperti dikritik oleh Pizzi dan Spence di muka. Pengadilan bukan lagi menjadi tempat untuk mencari kemenangan. Di muka sudah disinggung, bahwa kantor-kantor advokat bukan lagi berpapan nama "Kantor Keadilan", melainkan "Perusahaan Hukum" (law firm).

Nuansa komoditas disini sangat kuat. Persoalan pokok disini adalah bagaimana hukum menjadi alat dan teknologi untuk mendapatkan keuntungan materiel. Orang menjalani inisiasi (pendidikan hukum) untuk menjadi ahli hukum dengan cita-cita dan harapan untuk mendapat keuntungan dan kemewahan materiel. Orang belajar untuk lebih memenangkan suatu perkara dan dengan demikian tidak terlalu penting untuk memikirkan dimensi kemanusiaan hukum. Dengan amat bagus, Marc Galanter menggambarkan pergeseran dalam pelayanan hukum di Amerika Serikat yang tidak lagi bersifat 'individual practice", tetapi berubah menjadi 'hospital medicine' dengan karakteristik yang sudah diuraikan di muka.

Teknokratisasi hukum dan masinalisasi hukum adalah sebutan yang tepat untuk menggambarkan sosok hukum modern yang sudah mengalami kooptasi oleh ekonomi, khususnya kapitalisme. Alat pengukurpun berubah. Proses-proses hukum menjadi kurang dilihat sebagai medan untuk memperjuangkan dan memunculkan keadilan, tetapi lebih diukur dengan ukuran-ukuran ekonomi dan materi.

Dalam kepungan dunia yang demikian itu, maka pendidikan hukumpun terseret masuk menjadi bagian dari "tim sukses" hukum yang sudah menjadi materialistis seperti itu. Misalnya, sekarang kita berbicara mengenai pendidikan hukum berbasis kompetensi. Saya tidak heran apabila dalam atmosfer dunia seperti sekarang ini, kompetensi itu dikaitkan hal-hal yang bersifat teknologis dan materialistis. Dengan cara demikian kita hanya makin memperkuat pendidikan hukum sebagai bagian dari tim sukses tersebut di atas. 


\section{PENDIDIKAN HUKUM YANG BERDIMENSI MANUSIA DAN KEMANUSIAAN.}

Apabila kita ingin menjadikan pendidikan hukum sebagai avant garde dari perubahan kultur berhukum di Indonesia, maka sebaiknya kita berani muncul dengan gagasan "pendidikan hukum berbasis manusia dan kemanusiaan". Melalui cara tersebut maka seluruh kurikulum juga akan dirancang kembali menuju kepada gagasan baru tersebut, termasuk isi perkualiahan.

Untuk mewujudkan gagasan tersebut, pertama diusahakan agar filsafat yang mendasari pendidikan hukum bergeser "dari professional menjadi pro-manusia”. Dalam alam filsafat seperti itu, maka setiap berhadapan dengan masalah hukum, kita tidak pertama-tama berhadapan dengan "perkara hukum", melainkan dengan "masalah manusia dan kemanusiaan".

:Pergeseran tersebut menjadikan pendidikan hukum, bukan pertamatamakidan terutama sebagai pendidikan teknologi dan professional, melainkan menjadi tempat untuk mematangkan kemanusiaan. Mendidik mahasiswa untuk menjadi matang dalam kemanusiaan berbeda dengan mendidik mereka menjadi professional hukum, atau operator mesin hukum. Bukan hukum perdata, pidana, acara dan lain-lain penguasaan materi yang dida- hulukan, melainkan didahulukan pendidikan "untuk menjadi manusia". Semangat yang mendasari pendidikan hukum bukan bagaimana terampil dan kompeten secara professional, melainkan bagaimana "menolong manusia yang susah dan menderita".

Gagasan pendidikan hukum berbasis manusia dan kemanusiaan tersebut sejalan dengan kritik-kritik yang dilontarkan oleh Gerry Spence terhadap pendidikan hukum di Amerika Serikat ${ }^{6}$. Spence mengatakan, bahwa kelemahan para lawyer Amerika bukan terletak pada kompetensi profesionalnya, melainkan pada kelemahan mereka sebagai manusia. Ditulis oleh Spence, bahwa $^{7}$... But most lawyers don't recognize their incompetence. That's because their incompetence begins not as lawyers, but "as human beings ... Good trial lawyers nood not be evolved persons underneath all the lawyer stuff. Good trial lawyers must be able to speak the ordinary language of the people."

Pada waktu pintu masuk ke pendidikan hukum dibuka, maka pertama-tama para mahasiswa baru sudah dihadapkan kepada persoalan kemanusiaan yang akan menjadi landasan dan modal penting bagi keahlian hukum mereka nanti. Dengan demikian, begitu mereka

\footnotetext{
${ }^{6}$ Gerry, Sp̀ence. Op.Cit

${ }^{7}$ Gerry; Spence, Op,Cit.
} 
mengawali langkah ke dunia hukum, mereka segera disongsong oleh diskusi-diskusi soal-soal di seputar manusia, seperti keadilan, ketidakadilan, diskriminasi dalam masyarakat, kebenaran, penderitaan, mengasihi (caring), empati, kepedulian, keberanian (dare) dan compassion. Kompetensi-kompetensi kemanusiaan seperti itulah yang oleh Spence disebut sebagai "evolved persor" yang harus mendasari profesionalisme para lawyers.

Gagasan tentang pendidikan hukum berbasis manusia dan kemanusiaan mendorong para pengelola program pendidikan hukum untuk mendekonstruksi dan merekonstruksi hal-hal dan cara-cara yang selama ini dijalankan. Selama ini, misalnya, adagium "hakim memutus berdasarkan keyakinan" masih dibiarkan berlalu begitu begitu saja (taken for granted), tanpa merasa perlu untuk melakukan elaborasi secara psikologis, padahal disitulah dimasukkan faktorfaktor psikis tersebut diatas.

Mungkin, karena terlalu kuatnya positivisme dan legalisme dalam pendidikan hukum, maka hakimhakim kita takut untuk bertindak progresif. Mereka lebih menjadi orang-orang yang setia mutlak kepada kata-kata undang-undang daripada menjadi hakim progresif yang berani menggali makna dan melakukan rule-breaking. Sikap seperti ini tidak membantu
Indonesia keluar dari keterpurukan, seperti dalam penanganan perkaraperkara korupsi.

Sebagai konsekuensi dari pergeseran arah pendidikan menuju pendidikan kemanusiaan, maka bantuan-bantuan seperti disiplin behavioral sciences untuk membantu menjadikan pendidikan hukum kita lebih berdimensi manusia dan kemanusiaan. Untuk mengakomodasi hal-hal tersebut barangkali kita bisa memberikan porsi yang lebih substansial terhadap diskusi daripada kuliah-kuliah konvensional (lecturing) belaka. Melalui diskusi-diskusi tersebut mudah-mudahan perkara-perkara hukum bisa ditarik untuk lebih menjadi perkara-perkara manusia dan kemanusiaan.

Kita masih mempunyai satu keuntungan, oleh karena pendidikan hukum kita dinamakan "fakultas hukum" dan bukan "fakulti undangundang" seperti di Malaysia. Perbedaan ini hendaknya benar-benar dimanfaatkan, oleh karena arti hukum itu jauh lebih luas daripada undang-undang. Dalam konteks artikel ini, hukum kita baca sebagai institusi manusia dan kemanusiaan, sehingga pendidikan hukum juga menjadi bastion dari manusia dan kemanusiaan. 


\section{DAFTAR PUSTAKA}

de Beus, J.W. \& J.A.A. van Doorn, De geconstrueerde samanleving, Amsterdam : Boom Meppel, 1986.

Galanter, Marc, "Mega-Law and Mega-Lawyering in the Contemporary United States", dalam The Sociology of the Legal Professions, (Roberts Dingwall \& PhiliLewis, eds.), London : The Macmillan Press, 1983 ,

Pizzi, William T., Trials Without Truth, NY.: New York University Press, 1999.

Spence, Gerry, The Death of Justice, N.Y.: St. Martin's Press, 1997.

Unger, Roberto Mangabeira, Law in Modem Society, N.Y.: The Free Press, 1976. 